\title{
Stable conditional expression and effect of C/EBP $\beta$-LIP in adipocytes using the pSLIK system
}

\section{Cristina L Esteves, Val Kelly, Valérie Bégay', Simon G Lillico², Achim Leutz', Jonathan R Seckl and Karen E Chapman}

Endocrinology Unit, Queen's Medical Research Institute, University/BHF Centre for Cardiovascular Science, The University of Edinburgh, 47 Little France Crescent, Edinburgh EH16 4TJ, UK

${ }^{1}$ Max Delbrüeck Centre for Molecular Medicine, Robert-Rössle-Straße 10, 13125 Berlin, Germany

${ }^{2}$ Division of Developmental Biology, The Roslin Institute, The University of Edinburgh, Easter Bush Campus, Midlothian EH25 9RG, UK
Correspondence should be addressed to C L Esteves

Email

cristina.esteves@ed.ac.uk

\begin{abstract}
Murine 3T3-L1 adipocytes are widely used as a cellular model of obesity. However, whereas transfection of 3T3-L1 preadipocytes is straightforward, ectopic gene expression in mature 3T3-L1 adipocytes has proved challenging. Here, we used the pSLIK vector system to generate stable doxycycline-inducible expression of the liver-enriched inhibitor protein isoform of CCAAT/enhancer binding protein $\beta$ (CEPB (C/EBP $\beta$-LIP)) in fully differentiated 3T3-L1 adipocytes. Because overexpression of C/EBP $\beta$-LIP impairs adipocyte differentiation, the C/EBP $\beta$-LIP construct was first integrated in 3T3-L1 preadipocytes but expression was induced only when adipocytes were fully differentiated. Increased C/EBP $\beta$-LIP in mature adipocytes down-regulated C/EBP $\beta$ target genes including $11 \beta$-hydroxysteroid dehydrogenase type 1, phosphoenolpyruvate carboxykinase and fatty acid binding protein 4 but had no effect on asparagine synthetase, demonstrating that transcriptional downregulation by C/EBP $\beta$-LIP in 3T3-L1 adipocytes is not a general effect. Importantly, these genes were modulated in a similar manner in adipose tissue of mice with genetically increased C/EBP $\beta$-LIP levels. The use of the pSLIK system to conditionally express transgenes in 3T3-L1 cells could be a valuable tool to dissect adipocyte physiology.
\end{abstract}

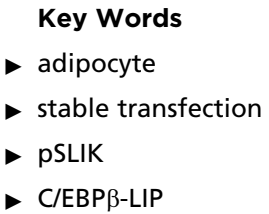

Journal of Molecular Endocrinology (2013) 51, 91-98

\section{Introduction}

First developed almost 40 years ago from Swiss mouse embryo cells, 3T3-L1 adipocytes (Otto \& Lane 2005, Rosen \& MacDougald 2006) have proved to be an invaluable tool, advancing our understanding of cellular mechanisms underlying obesity-related disorders. However, introduction of nucleic acids and, consequently, the manipulation of genes in fully differentiated 3T3-L1 adipocytes are difficult to achieve. pSLIK plasmids, encoding a tetracycline-regulated transcriptional unit in a lentivirus-based vector backbone, were originally designed to facilitate stable transduction of microRNA-like short hairpin RNAs into RAW264.7 cells (Shin et al. 2006) but have not been tested in adipocytes.

The transcription factor CCAAT/enhancer binding protein $\beta(\mathrm{CEBPB}(\mathrm{C} / \mathrm{EBP} \beta))$ is produced as three major isoforms resulting from differential use of in-frame translation start sites or from proteolysis (Ossipow et al. 1993, Welm et al. 1999, Calkhoven et al. 2000); the 38 and $35 \mathrm{kDa}$ liver-enriched activator protein isoforms (C/EBP $\beta$-LAP* and $\mathrm{C} / \mathrm{EBP} \beta$-LAP respectively) and the $20 \mathrm{kDa}$ liver-enriched 
inhibitor protein (LIP; C/EBP $\beta$-LIP). C/EBP $\beta$-LIP contains the carboxyl-terminal dimerisation and DNA binding domains but lacks the amino-terminal activation domain of C/EBP $\beta$ LAP (Ramji \& Foka 2002). Consequently, C/EBP $\beta$-LIP represses transcription by forming either homodimers or heterodimers with the C/EBP $\beta$-LAP isoforms or other C/EBPs (Descombes et al. 1990, Calkhoven et al. 2000) and manipulation of C/EBP $\beta$-LIP levels may change C/EBP $\beta$ LIP:LAP ratio. However, the majority of reports do not differentiate between $\mathrm{C} / \mathrm{EBP} \beta$ isoforms, and genetic disruption of the encoding gene eliminates production of all isoforms. While $\mathrm{C} / \mathrm{EBP} \beta$ is well recognised as a major player in adipocyte differentiation and metabolism, the role of the specific isoforms, and especially the C/EBP $\beta$-LIP isoform, is less clear. We have recently shown that genetic manipulation of levels of C/EBP $\beta$-LIP in vivo changes adipose tissue expression of the C/EBP $\beta$ target gene that encodes the glucocorticoid amplifying enzyme 11ß-hydroxysteroid dehydrogenase type 1 (Hsd11b1 (11ß-HSD1); Seckl et al. 2004, Esteves et al. 2012). However, exploration of mechanisms in 3T3-L1 adipocytes is hindered by the impairment of preadipocyte differentiation by C/EBP $\beta$-LIP (Yeh et al. 1995, Payne et al. 2007, Abdou et al. 2011).

Here, we have used the pSLIK system to generate stable inducible expression of C/EBP $\beta$-LIP in 3T3-L1 adipocytes. Increased levels of C/EBP $\beta$-LIP in 3T3-L1 adipocytes decreased the expression of the metabolically relevant C/EBP $\beta$ target genes encoding phosphoenolpyruvate carboxykinase (Pck1 (PEPCK)), fatty acid binding protein 4 (Fabp4 (FABP4)) and asparagine synthetase in a manner similar to manipulation of C/EBPß-LIP in vivo.

\section{Materials and methods}

\section{Ethics statement}

All animal experiments were conducted in strict accordance with internationally accepted standards of humane animal care following prior approval by the Institutional Animal Care and Use Committee in Berlin, Germany.

\section{Cells and animals}

Murine 3T3-L1 preadipocytes (American Type Culture Collection (ATCC)) were maintained in DMEM (Lonza, Cambridge, UK) supplemented with newborn calf serum (10\%; Lonza), unless otherwise stated. Adult male C/EBP $\beta$ mutant mice, heterozygous $\mathrm{C} / \mathrm{EBP}^{(+/ \mathrm{L})}$, homozygous $\mathrm{C} / \mathrm{EBP} \beta^{\triangle \mathrm{uORF}}$ and respective wild-type (WT) littermate control mice ( $n=6-7 /$ group) were generated as described previously (Smink et al. 2009, Wethmar et al. 2010).

\section{Stable transfection of 3T3-L1 preadipocytes}

C/EBP $\beta$-LIP DNA sequence was excised from pMSVC/EBP $\beta$ (a gift from S L McKnight and W-C Yeh), ligated to an internal ribosome entry site (IRES) to allow for downstream GFP expression and the resulting C/ЕВP $\beta$ LIP-IRES construct was cloned into pMBA-266. C/EBP $\beta$-LIP and control (empty) pSLIK vectors (Shin et al. 2006) were generated by gateway recombination between a pEN (MBA-266; ATCC) entry vector harbouring C/EBPß-LIP or empty vector and the pSLIK-Neo destination vector (MBA-235; ATCC). 3T3-L1 preadipocytes were transfected with control or C/EBP $\beta$-LIP-expressing pSLIK vectors using Lipofectamine 2000 (Invitrogen), followed by $\geq 15$-day selection of cells resistant to $1 \mathrm{mg} / \mathrm{ml}$ geneticin (Invitrogen). Transfection efficiency was high (data not shown) and a total pool of transfected preadipocytes was obtained. Both control and C/EBP $\beta$-LIP transfectants expressed GFP in the presence of doxycycline (DOX; $1 \mu \mathrm{g} / \mathrm{ml}$; Sigma) and were further selected by cell sorting in the presence of DOX (FACSVantage, BD Biosciences, San Jose, CA, USA). Preadipocytes were maintained throughout in geneticin.

\section{Differentiation of 3T3-L1 preadipocytes into adipocytes}

3T3-L1 preadipocytes, cultured in the absence of DOX, harbouring C/EBP $\beta$-LIP or control empty vector, were induced to differentiate into mature adipocytes as described previously (Napolitano et al. 1998). Cells were grown to confluence, and 2 days later, they were induced to differentiate in DMEM supplemented with $10 \%$ FCS, $0.5 \mu \mathrm{M}$ dexamethasone, $500 \mu \mathrm{M}$ 3-isobutyl-1-methylxanthine and $5 \mu \mathrm{g} / \mathrm{ml}$ insulin for 2 days. Thereafter, 3T3-L1 cell differentiation continued in medium supplemented with $5 \mu \mathrm{g} / \mathrm{ml}$ insulin alone. Experiments were performed 8-12 days following induction of differentiation, unless otherwise stated. DOX $(1 \mu \mathrm{g} / \mathrm{ml})$ was added to the medium in the experiments designed to induce C/EBP $\beta$-LIP.

\section{Western blot analysis}

Cells were harvested in lysis buffer $(0.125 \mathrm{M}$ Tris-HCL, $\mathrm{pH} 6.8,2 \%$ SDS and $10 \%$ glycerol) in the presence of a protease inhibitor cocktail (P2714; Sigma) and heated at $100{ }^{\circ} \mathrm{C}$. Electrophoresis was carried out on $4-12 \%$ NuPage Bis-Tris gels (Invitrogen). After transfer, blots were probed with antibodies to C/ЕВP $\beta$ (1:500 dilution of stock $200 \mu \mathrm{g} / \mathrm{ml}$; Santa Cruz Biotechnology, Inc.) and $\beta$-tubulin (1:10 000 dilution; Chemicon/Millipore, Watford, UK). Secondary antibodies were anti-rabbit

Published by Bioscientifica Ltd 
IgG-HRP (1:2000 dilution from stock $400 \mu \mathrm{g} / \mathrm{ml}$; Santa Cruz Biotechnology, Inc.), anti-mouse IgG-HRP (1:4000 dilution; Cell Signaling, Danvers, MA, USA), anti-rabbit IgG Alexa Fluor 700 (Invitrogen) or anti-mouse IgG 488 Conjugated (Rockland Immunochemicals, Inc., Gilbertsville, PA, USA). The resulting bands were visualised on X-ray films developed in a Konica SRX-101 X-Ray developer or using the Odyssey Infrared Imaging System, as appropriate.

\section{Oil Red O staining}

3T3-L1 adipocytes were stained by Oil Red O as described previously (Lillie \& Ashburn 1943) with modifications.

A

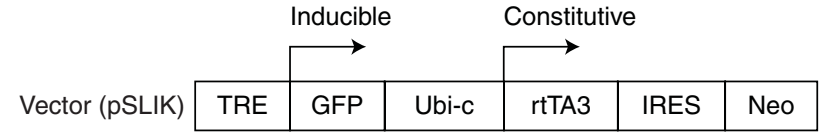

\begin{tabular}{|l|l|l|l|l|l|l|l|l|}
\cline { 2 - 7 } LIP (pSLIK-LIP) & TRE & LIP & IRES & GFP & Ubi-c & rtTA3 & IRES & Neo \\
\cline { 2 - 6 }
\end{tabular}

B
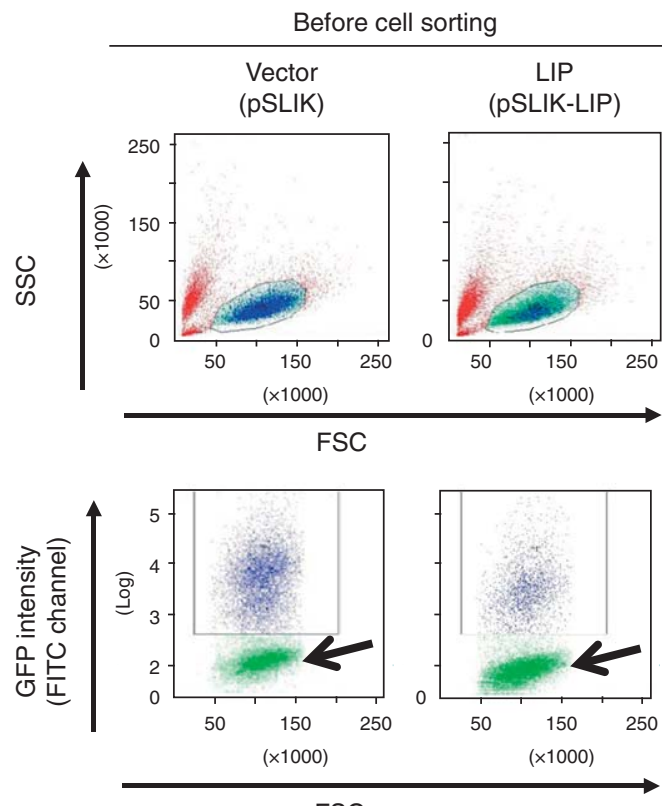

FSC

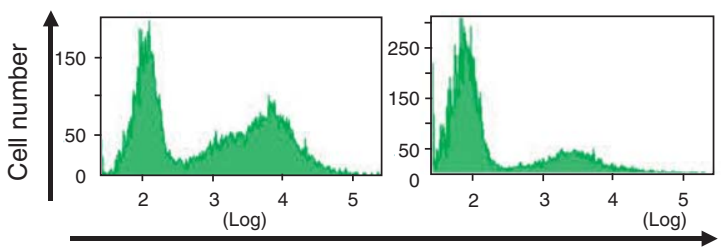

GFP intensity (FITC channel)
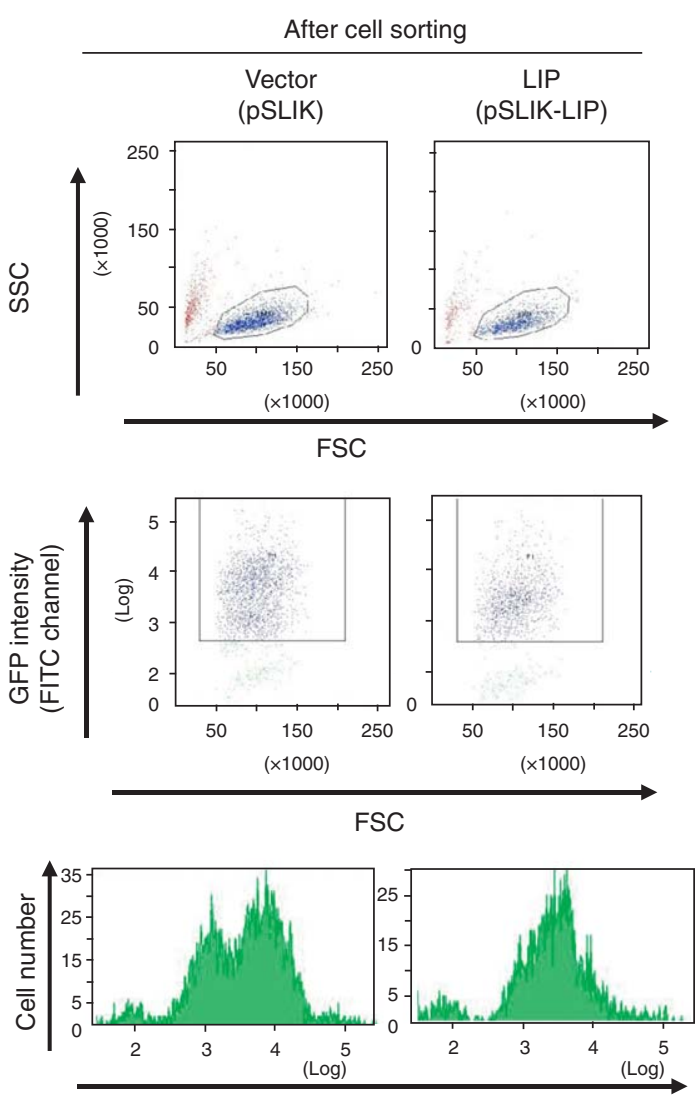

GFP intensity (FITC channel)
Figure 1

The PSLIK-C/EBP $\beta$-LIP construct and generation of stably transfected 3T3-L1 preadipocytes. (A) Schematic representation of the pSLIK Tet-On empty vector (top; vector, pSLIK) and construct used to generate stable 3T3-L1 preadipocytes conditionally overexpressing C/EBP $\beta$-LIP (bottom; LIP, pSLIKC/EBP $\beta$-LIP). C/EBP $\beta$-LIP and GFP are co-expressed from the same transcript. The constitutively active ubiquitin c (Ubi-c) promoter drives expression of the Tet activator (rtTA3) and neomycin resistance gene (Neo; for selection). Addition of DOX causes binding of rTTA3 to the TRE/CMV promoter (TRE), inducing expression of GFP or C/EBPB-LIP-IRES-GFP. (B) FACS analysis and sorting of 3T3-L1 preadipocytes $\left(5 \times 10^{6}\right.$ cells) stably transfected with
pSLIK-C/EBP $\beta$-LIP (LIP) or PSLIK vector (vector) following DOX treatment $(1 \mu \mathrm{g} / \mathrm{ml}, 24 \mathrm{~h})$ to induce GFP. Upper panels, forward scatter (FSC) vs side scatter (SSC) dot plots, showing the populations of single cells (circled) that were analysed and sorted for GFP expression (FSC vs GFP intensity plots; middle row of panels) and histogram showing the number of cells for GFP intensity (lower panels). Middle and lower panels show the enrichment of GFP-positive cells for both PSLIK-C/EBP $\beta$-LIP and pSLIK cells after sorting (right panels) resulting from the removal of low or non-GFP-expressing preadipocytes (arrow; left panels). http://jme.endocrinology-journals.org DOI: 10.1530/JME-13-0029
C 2013 The authors Printed in Great Britain
Published by Bioscientifica Ltd 
Cells were immersed in isopropanol (60\%), followed by the staining solution (0.04\% Oil Red O in 60\% isopropanol) and ammonia (1\%) and then visualised using a Zeiss Axioskop microscope. Quantification of Oil Red O staining density was performed with ImageJ (NIH, Bethesda, MA, USA).

\section{RNA extraction and real-time PCR}

Cells were harvested in TRIzol (Invitrogen) and RNA was extracted according to the manufacturer's protocol. Mouse subcutaneous adipose tissue was dissected and frozen $\left(-70^{\circ} \mathrm{C}\right)$ prior to RNA extraction using Qiagen RNeasy Lipid Tissue Mini kit (Qiagen). RNA ( $1 \mu \mathrm{g})$ was reverse transcribed using SuperScript III (Invitrogen), and specific mRNAs were quantified by real-time PCR using a LightCycler 480 (Roche) as described (Sai et al. 2008). Primer-probe sets were purchased from Applied Biosystems: C/EBP $\beta$ (Mm00843434_s1), 11 $\beta$-HSD1 (Mm00476182_m1), PEPCK (Mm01247058_m1), FABP4 (Mm00445878_m1) and asparagine synthetase $(\mathrm{Mm}$ 00803785_m1). TATA binding protein (TBP; $\mathrm{Mm}$ 00446973_m1) was used as internal control and did not change with treatment or between groups.

\section{Statistical analysis}

All data were analysed by Student's $t$-test or one-way ANOVA followed by post hoc least square difference test using SigmaStat 2.03 Statistical Software. Significance was set at $P \leq 0.05$.

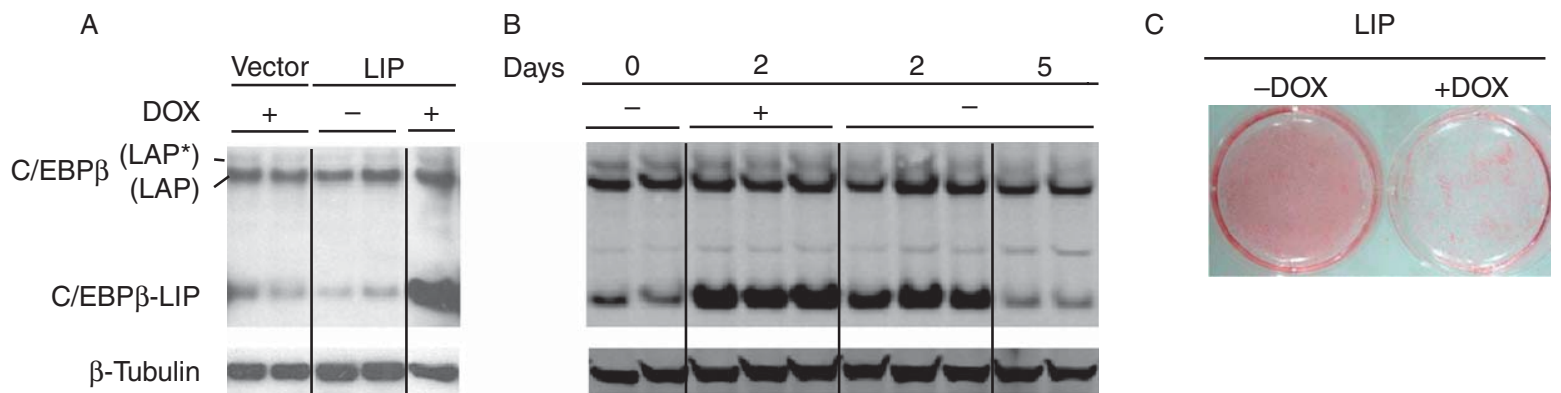

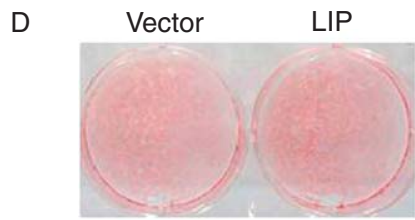

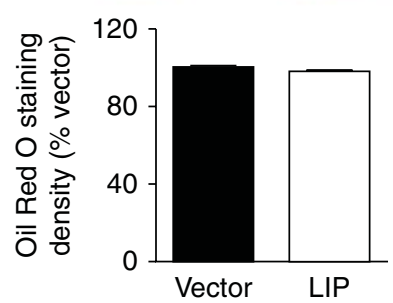

(a)
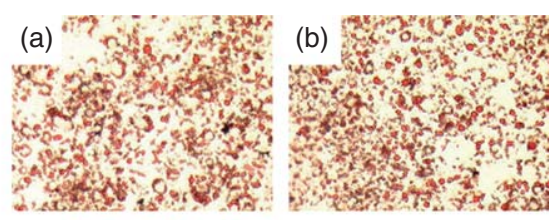

(c)

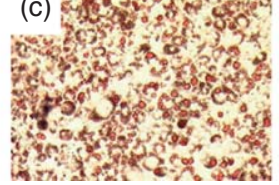

\section{Figure 2}

Doxycycline-inducible expression of C/EBP $\beta$-LIP in fully differentiated adipocytes and adipocyte differentiation visualised by Oil Red $O$ staining. (A) Western blot showing induction of C/EBP $\beta$-LIP expression in 3T3-L1 pSLIK-C/EBP $\beta$-LIP (LIP, + DOX) or pSLIK control vector (vector, + DOX) adipocytes. Preadipocytes were differentiated into adipocytes in DOX-free medium. Mature adipocytes were then treated with DOX for 2 days. In the absence of DOX, C/EBP $\beta$-LIP levels were not elevated above basal endogenous levels in pSLIK-C/EBP $\beta$-LIP adipocytes (LIP, -DOX). The blot (40 $\mu \mathrm{g}$ protein/lane) was probed with C/EBP $\beta$ antibody (38 kDa LAP*, $35 \mathrm{kDa}$ LAP and $20 \mathrm{kDa}$ LIP are indicated), then stripped and reprobed with $\beta$-tubulin antibody, as loading control. All samples in each membrane were analysed in the same gel, but not in adjacent lanes. (B) Western blot showing robust induction of C/EBP $\beta$-LIP in pSLIK-C/EBP $\beta$-LIP adipocytes, previously differentiated in DOX-free medium and then treated with DOX between days 0 and 2 . Samples ( $50 \mu \mathrm{g}$ protein/lane) were taken before treatment (0), 2 days after DOX-induction of C/EBPB-LIP $(2 ;+D O X)$ and 2 and 5 days following DOX withdrawal from the medium ( 2 and $5 ;-D O X$ ). ( $C$ and $D$ ) Oil Red $O$ staining showing lipid accumulation in differentiated adipocytes. 3T3-L1 pSLIK-C/EBP $\beta$-LIP preadipocytes were differentiated into adipocytes in the presence (+DOX) or absence (-DOX) of DOX (C) or were differentiated in the absence of DOX and then DOX-treated for 3 days prior to Oil Red O staining (D). Panels show differentiated adipocytes; pSLIKC/EBP $\beta$-LIP (LIP; b), pSLIK control vector (vector; a) and untransfected 3T3-L1 adipocytes (c). Objective magnification, $\times 10$.

Published by Bioscientifica Ltd http://jme.endocrinology-journals.org DOI: 10.1530/JME-13-0029 (c) 2013 The authors Printed in Great Britain 


\section{Results}

\section{Conditional expression of C/EBP $\beta$-LIP in stably transfected 3T3-L1 preadipocytes and differentiated adipocytes}

To generate a vector to conditionally express C/EBP $\beta$-LIP, the encoding cDNA was cloned and recombined in the
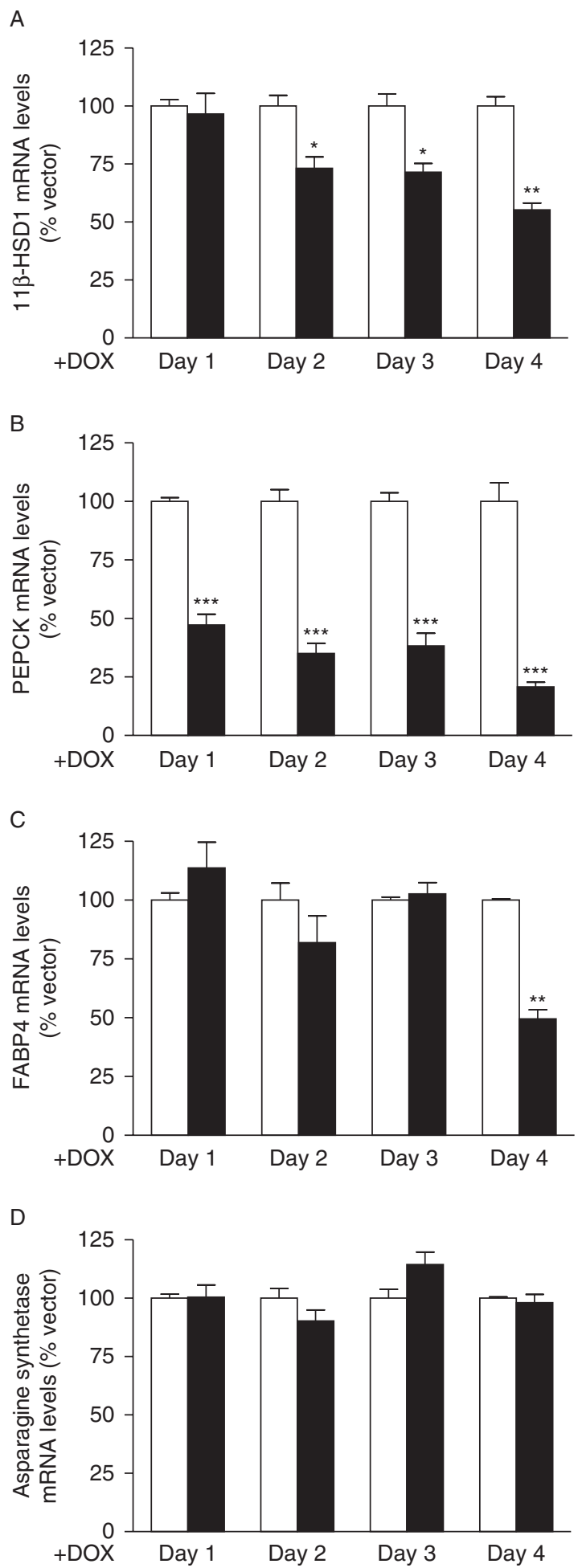

http://jme.endocrinology-journals.org DOI: 10.1530/JME-13-0029
MBA-266 and the pSLIK-Neo MBA-235 vectors, respectively, producing the pSLIK-C/EBP $\beta$-LIP vector in which a tetracycline response element drives expression of C/EBP $\beta$-LIP from a minimal CMV promoter in the presence of DOX (a Tet-ON system) and a contiguous IRES allows for GFP expression. Constitutive expression of the reverse Tet transactivator (rtTA3) and the neomycin resistance gene (Neo) is driven by the ubiquitin-c (Ubi-c) promoter (Fig. 1A). In order to express $\mathrm{C} / \mathrm{EBP} \beta$-LIP in mature adipocytes, we first generated stably transfected 3T3-L1 preadipocytes that, in contrast to fully differentiated adipocytes, could be readily transfected with pSLIK-C/EBPß-LIP or the 'empty' vector. This was highly efficient allowing selection of transfectants with geneticin as a total pool of cells, avoiding clonal differences due to plasmid integration site. To ensure that only transfected cells were used in the subsequent experiments, preadipocytes were sorted by flow cytometry for GFP expression $24 \mathrm{~h}$ after incubation with DOX, with yields of 26 and 56\% for pSLIK-C/EBP $\beta$-LIP and pSLIK-transfectants respectively (Fig. 1B). In the absence of DOX, only $0.9 \%$ of pSLIK-C/EBP $\beta$-LIP and $4.3 \%$ of pSLIK preadipocytes were GFP positive, demonstrating low spontaneous expression in the transfected preadipocytes. pSLIK-C/EBP $\beta$-LIP preadipocytes were then differentiated into mature adipocytes in DOX-free medium (to avoid the inhibitory effects of C/EBP $\beta$-LIP upon adipocyte differentiation) and subsequent DOX treatment robustly increased cellular C/EBP $\beta$-LIP levels in the mature adipocytes (Fig. 2A and B). Following removal of DOX from the cell medium, C/EBP $\beta$-LIP decreased as expected, showing that it can be transiently induced (Fig. 2B). Importantly, in the absence of DOX, pSLIKC/EBP $\beta$-LIP adipocytes showed comparable low endogenous levels of C/EBP $\beta$-LIP to control adipocytes harbouring the pSLIK empty vector (Fig. 2A).

\section{Figure 3}

Elevated adipocyte C/EBP $\beta$-LIP represses expression of C/EBP $\beta$ target genes but not of asparagine synthetase. Real-time PCR measurement of levels of mRNAs encoding (A) 11 $\beta$-HSD1, (B) PEPCK, (C) FABP4 and (D) asparagine synthetase in 3T3-L1 pSLIK-C/EBP $\beta$-LIP adipocytes (black bars) compared with PSLIK control adipocytes (white bars), following 1-4 days of induction with DOX. Preadipocytes were differentiated into adipocytes in DOX-free medium and DOX was added to mature adipocytes to induce C/EBP $\beta$-LIP expression. Levels of specific mRNAs, normalised to TBP are expressed relative to levels in pSLIK adipocytes (arbitrarily set to $100 \%$ ). Data are mean \pm s.E.M. of two independent adipocyte differentiations, each carried out in triplicate. *Significantly different from pSLIK control adipocytes. $* P \leq 0.05, * * P<0.001$ and $* * * P<0.0001$.

Published by Bioscientifica Ltd 
3T3-L1 preadipocytes stably transfected with pSLIK-C/EBP $\beta$-LIP differentiate normally into adipocytes

Consistent with previous data (Yeh et al. 1995, Payne et al. 2007, Abdou et al. 2011), adipocyte differentiation (demonstrated by Oil Red $\mathrm{O}$ staining of lipid) was markedly attenuated if C/EBP $\beta$-LIP expression was induced in 3T3L1 pSLIK-C/EBP $\beta$-LIP preadipocytes prior to and during differentiation by DOX (Fig. 2C). In contrast, when pSLIK$\mathrm{C} / \mathrm{EBP} \beta$-LIP preadipocytes were differentiated in the absence of DOX, both pSLIK control and pSLIK-C/EBP $\beta$-LIP preadipocytes differentiated normally into mature adipocytes. Induction of $\mathrm{C} / \mathrm{EBP} \beta$-LIP in fully differentiated adipocytes had no effect on their differentiation status as shown by quantification of Oil Red O staining (Fig. 2D).

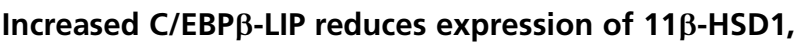 PEPCK and FABP4 but not asparagine synthetase in 3T3-L1 mature adipocytes}

The transcriptional impact of increased C/EBP $\beta$-LIP in adipocytes was examined following induction with DOX only once 3T3-L1 adipocytes were fully differentiated. Concurrent with the increase in C/EBP $\beta$-LIP expression, and consequently C/EBP $\beta$-LIP:LAP ratio, DOX reduced $11 \beta$-HSD1 and PEPCK mRNA levels in 3T3-L1 pSLIK-C/EBP $\beta$-LIP adipocytes compared with control cells (Fig. 3A and B). FABP4 mRNA levels were decreased following 4 days of DOX treatment but asparagine synthetase mRNA levels were unaffected (Fig. 3C and D).

\section{Modulation of C/EBP $\beta$-LIP levels in adipose tissue in vivo changes the expression of PEPCK and FABP4}

To test the relevance of the 3T3-L1 pSLIK-C/EBP $\beta$-LIP adipocyte model to the in vivo situation, we measured the levels of mRNA encoding PEPCK, FABP4 and asparagine synthetase in the adipose tissue of mice genetically engineered to produce altered levels of C/EBP $\beta$-LIP, which we have previously shown to regulate adipose tissue 11ß-HSD1 mRNA levels (Esteves et al. 2012). $\mathrm{C} / \mathrm{EBP} \beta^{(+/ L)}$ mice, with a 'knock-in' of C/EBP $\beta$-LIP (L allele) replacing the normal C/EBP $\beta$ gene, have increased C/EBP $\beta$-LIP levels and therefore increased C/EBP $\beta$-LIP:LAP ratio (Smink et al. 2009). In contrast, in $C / E B P \beta^{\triangle \mathrm{uORF}}$ mice, deletion of the upstream open reading frame $(\Delta \mathrm{uORF}$ allele) prevents translation of C/EBP $\beta$-LIP (Wethmar et al. 2010), resulting in decreased C/EBP $\beta$-LIP:LAP ratio (Esteves et al. 2012). In agreement with the results obtained in the 3T3-L1 pSLIK-C/EBP $\beta$-LIP adipocytes, levels of mRNA encoding PEPCK were lower in the adipose tissue of $\mathrm{C} / \mathrm{EBP}^{(+/ \mathrm{L})}$ mice compared with $\mathrm{C} / \mathrm{EBP} \beta^{\mathrm{\Delta uORF}}$ (Fig. 4A). However, there was no significant decrease in PEPCK mRNA levels in $\mathrm{C} / \mathrm{EBP}^{(+/ L)}$ mice compared with WT controls, suggesting a larger effect of C/EBP $\beta$-LIP
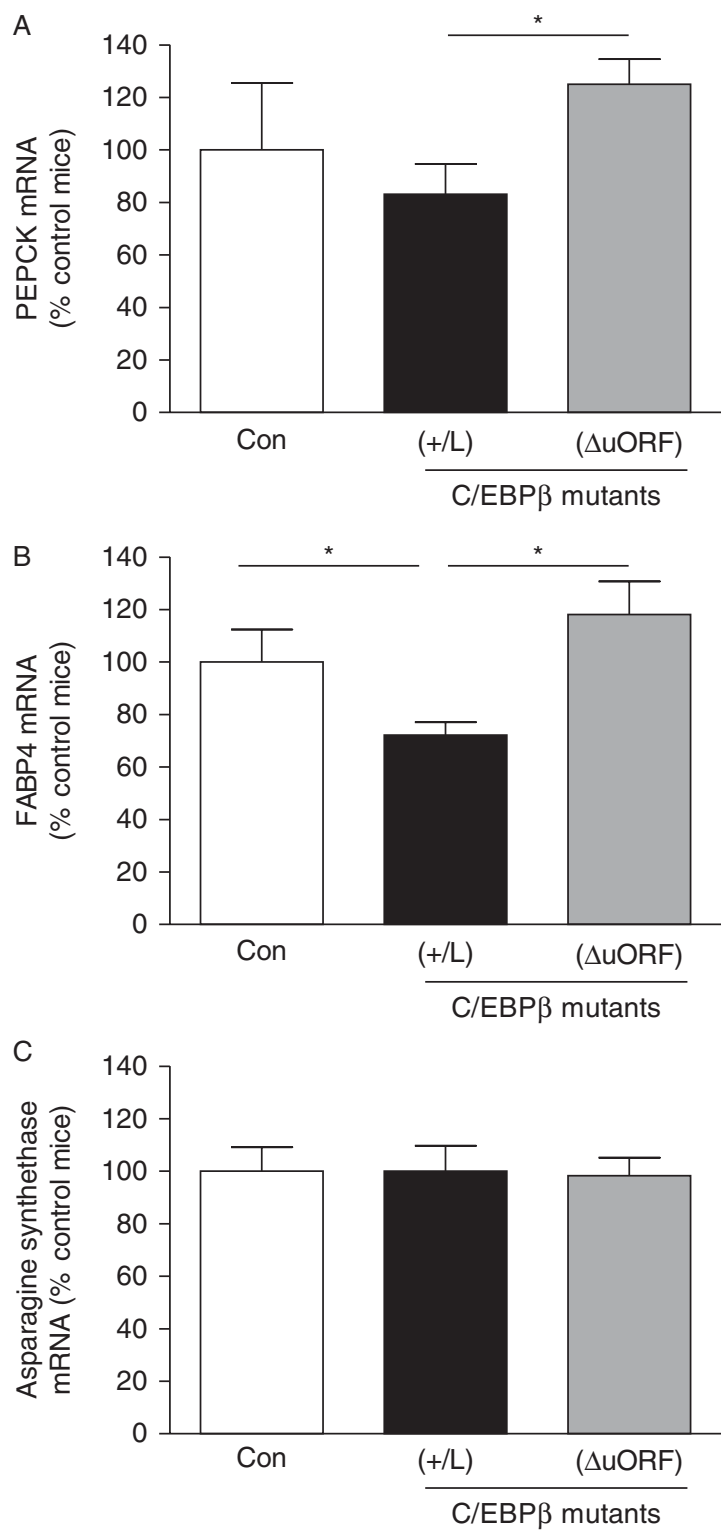

Figure 4

Elevated C/EBP $\beta$-LIP represses expression of PEPCK and FABP4, but not asparagine synthetase in adipose tissue in vivo. Real-time PCR measurement of levels of mRNA encoding (A) PEPCK, (B) FABP4 and (C) asparagine synthetase in adipose tissue of wild-type control mice (Con, white bars), C/EBP $\beta^{(+/ L)}\left(+/ L\right.$, black bars) and C/EBP $\beta^{\triangle \mathrm{UORF}}(\Delta \mathrm{UORF}$, grey bars). C/EBP $\beta^{(+/ L)}$ mice are heterozygous for an allele of $C / E B P \beta$ in which the normal gene has been replaced by C/EBP $\beta$-LIP (a 'knock-in'; Smink et al. 2009) and C/EBP $\beta^{\triangle \mathrm{uORF}}$ mice have a homozygous disruption of the upstream ORF (Wethmar et al. 2010). Adipose tissue mRNA levels, normalised to TBP, are expressed relative to levels in control mice (arbitrarily set to $100 \%$ ) and are mean \pm S.E.M.; $n=6$-9/group. ${ }^{*} P \leq 0.05$.

Published by Bioscientifica Ltd 
in vitro than in vivo or that compensation has occurred in vivo (e.g. through tissues other than adipose). FABP4 levels were lower in the adipose of $\mathrm{C} / \mathrm{EBP}^{(+/ L)}$ mice compared with control and C/EBP $\beta^{\triangle \mathrm{uORF}}$ mice, while asparagine synthetase was unchanged (Fig. $4 \mathrm{~B}$ and C). Taken together, these results show that the 3T3-L1 pSLIK$\mathrm{C} / \mathrm{EBP} \beta$-LIP adipocytes mimic the in vivo regulation.

\section{Discussion}

The use of the pSLIK system to conditionally express C/EBP $\beta$-LIP in fully differentiated 3T3-L1 mature adipocytes allowed investigating its impact on the transcriptional levels of 11ß-HSD1, PEPCK, FABP4 and asparagine synthetase in these cells. Although transfection of adipocytes with small RNAs (siRNA and shRNA) has recently been achieved using nanoparticles of virusderived amphipathic peptides (Li et al. 2007, Esteves et al. 2012), transfection of vectors harbouring expression cassettes remains a challenge. Electroporation, used in some studies (Thurmond et al. 1998), causes high levels of adipocyte death, is inefficient, and requires large amounts of DNA (or RNA). Adenovirus transduction allows expression of exogenous genes in 3T3-L1 adipocytes (Gnudi et al. 1997, Boizard et al. 1998, Duong et al. 2002, Carlotti et al. 2004) but does not produce stable expression and can induce immune responses. Many genes expressed in adipocytes, including 11ß-HSD1 (Chapman et al. 2009), are immunoresponsive (Shoelson et al. 2006). Lentiviral vectors can be used to stably transduce adipocytes but require production of high titres of virus (Carlotti et al. 2004, Liao et al. 2006). The pSLIK vector used in the current study was originally designed as an intermediate in lentiviral construction (Shin et al. 2006) and combines all components required for expression (Tet-ON) and selection (Neo, GFP) in a single plasmid vector. This allows for the transfection of the pSLIK-C/EBP $\beta$-LIP vector into 3T3-L1 preadipocytes without the need for lentivirus and proves a highly efficient process. Here, we used DOX to restrict expression of C/EBP $\beta$-LIP to fully differentiated 3T3-L1 adipocytes, but ectopic transgene expression can be initiated at any stage of 3T3-L1 adipocyte differentiation or even induced transiently. Moreover, it may prove useful for expression of shRNA in differentiated adipocytes, to conditionally knockdown gene expression. Contrary to standard lentiviral transduction of adipocytes, here, all adipocytes harbour the gene of interest and expression is achieved soon after induction with DOX.

Elevation of C/EBP $\beta$-LIP in mature differentiated 3T3-L1 adipocytes concomitantly decreased PEPCK and 11ß-HSD1
mRNA levels, suggesting direct regulation of 11ß-HSD1 by C/EBP $\beta$-LIP in adipocytes. Indeed, both genes are bound by C/EBP $\beta$ and this has been shown for $11 \beta$-HSD1 in several cell types (Arai et al. 2007, Sai et al. 2008, Yang et al. 2009), including adipocytes (Esteves et al. 2012), and for PEPCK in hepatoma cells (Park et al. 1993, Choudhury et al. 2011). PEPCK mRNA levels declined faster than other genes, possibly reflecting the short half-life of PEPCK (Tilghman et al. 1974) compared with 11ß-HSD1 mRNA, for example (Balachandran et al. 2008). FABP4 mRNA levels were only affected after more prolonged elevation of C/EBP $\beta$-LIP, suggesting that either the mRNA is very stable or regulation is indirect. However, $\mathrm{C} / \mathrm{EBP} \beta$-LIP expression did not depress global transcription in adipocytes, as asparagine synthetase mRNA levels were unaffected by elevated adipocyte C/EBP $\beta$ LIP both in vitro and in vivo. This contrasts with the HepG2 hepatoma cells where asparagine synthase is regulated by the C/EBPß-LIP:LAP ratio (Siu et al. 2001) and might reflect differences in epigenetic regulation.

Finally, we note that this system may be of broader application to explore the role of other adipocyte relevant genes in fully differentiated adipocytes, providing insights into their effect on adipocyte physiology.

\section{Declaration of interest}

The authors declare that there is no conflict of interest that could be perceived as prejudicing the impartiality of the research reported.

\section{Funding}

This work was supported by the Wellcome Trust Programme Grant (grant number WT083184 to J R S and K E C).

\section{Acknowledgements}

The authors thank Prof. Bruce Whitelaw for advice and members of the Endocrinology Unit for helpful discussions.

\section{References}

Abdou HS, Atlas E \& Hache RJ 2011 Liver-enriched inhibitory protein (LIP) actively inhibits preadipocyte differentiation through histone deacetylase 1 (HDAC1). Journal of Biological Chemistry 286 21488-21499. (doi:10.1074/jbc.M110.211540)

Arai N, Masuzaki H, Tanaka T, Ishii T, Yasue S, Kobayashi N, Tomita T, Noguchi M, Kusakabe T, Fujikura J et al. 2007 Ceramide and adenosine $5^{\prime}$-monophosphate-activated protein kinase are two novel regulators of $11 \beta$-hydroxysteroid dehydrogenase type 1 expression and activity in cultured preadipocytes. Endocrinology 148 5268-5277. (doi:10.1210/en. 2007-0349)

Balachandran A, Guan H, Sellan M, van Uum S \& Yang K 2008 Insulin and dexamethasone dynamically regulate adipocyte $11 \beta$-hydroxysteroid dehydrogenase type 1. Endocrinology 149 4069-4079. (doi:10.1210/en. 2008-0088) http://jme.endocrinology-journals.org

DOI: 10.1530/JME-13-0029 (c) 2013 The authors Printed in Great Britain
Published by Bioscientifica Ltd 
Boizard M, Le Liepvre X, Lemarchand P, Foufelle F, Ferre P \& Dugail I 1998 Obesity-related overexpression of fatty-acid synthase gene in adipose tissue involves sterol regulatory element-binding protein transcription factors. Journal of Biological Chemistry 273 29164-29171. (doi:10.1074/ jbc.273.44.29164)

Calkhoven CF, Muller C \& Leutz A 2000 Translational control of C/EBP $\alpha$ and C/EBP $\beta$ isoform expression. Genes and Development 14 1920-1932. (doi:10.1101/gad.14.15.1920)

Carlotti F, Bazuine M, Kekarainen T, Seppen J, Pognonec P, Maassen JA \& Hoeben RC 2004 Lentiviral vectors efficiently transduce quiescent mature 3T3-L1 adipocytes. Molecular Therapy 9 209-217. (doi:10.1016/j. ymthe.2003.11.021)

Chapman KE, Coutinho AE, Gray M, Gilmour JS, Savill JS \& Seckl JR 2009 The role and regulation of $11 \beta$-hydroxysteroid dehydrogenase type 1 in the inflammatory response. Molecular and Cellular Endocrinology $\mathbf{3 0 1}$ 123-131. (doi:10.1016/j.mce.2008.09.031)

Choudhury M, Qadri I, Rahman SM, Schroeder-Gloeckler J, Janssen RC \& Friedman JE $2011 \mathrm{C} / \mathrm{EBP} \beta$ is AMP kinase sensitive and up-regulates PEPCK in response to ER stress in hepatoma cells. Molecular and Cellular Endocrinology 331 102-108. (doi:10.1016/j.mce.2010.08.014)

Descombes P, Chojkier M, Lichtsteiner S, Falvey E \& Schibler U 1990 LAP, a novel member of the C/EBP gene family, encodes a liver-enriched transcriptional activator protein. Genes and Development 4 1541-1551. (doi:10.1101/gad.4.9.1541)

Duong DT, Waltner-Law ME, Sears R, Sealy L \& Granner DK 2002 Insulin inhibits hepatocellular glucose production by utilizing liver-enriched transcriptional inhibitory protein to disrupt the association of CREBbinding protein and RNA polymerase II with the phosphoenolpyruvate carboxykinase gene promoter. Journal of Biological Chemistry $\mathbf{2 7 7}$ 32234-32242. (doi:10.1074/jbc.M204873200)

Esteves CL, Kelly V, Begay V, Man TY, Morton NM, Leutz A, Seckl JR \&

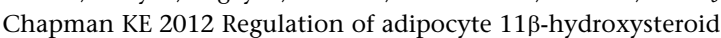
dehydrogenase type 1 (11ß-HSD1) by CCAAT/enhancer-binding protein (C/EBP) $\beta$ isoforms, LIP and LAP. PLoS ONE 7 e37953. (doi:10. 1371/journal.pone.0037953)

Gnudi L, Frevert EU, Houseknecht KL, Erhardt P \& Kahn BB 1997 Adenovirus-mediated gene transfer of dominant negative ras(asn17) in 3T3L1 adipocytes does not alter insulin-stimulated P13-kinase activity or glucose transport. Molecular Endocrinology 11 67-76. (doi:10.1210/ me.11.1.67)

Li J, Peters PJ, Bai M, Dai J, Bos E, Kirchhausen T, Kandror KV \& Hsu VW 2007 An ACAP1-containing clathrin coat complex for endocytic recycling. Journal of Cell Biology 178 453-464. (doi:10.1083/jcb.200608033)

Liao W, Nguyen MT, Imamura T, Singer O, Verma IM \& Olefsky JM 2006 Lentiviral short hairpin ribonucleic acid-mediated knockdown of GLUT4 in 3T3-L1 adipocytes. Endocrinology 147 2245-2252. (doi:10. 1210/en.2005-1638)

Lillie RD \& Ashburn LL 1943 Supersaturated solutions of fat stains in dilute isopropanol for demonstration of acute fatty degeneration not shown by Herxheimer's technique. Archives of Pathology 36 432-440.

Napolitano A, Voice MW, Edwards CR, Seckl JR \& Chapman KE 1998 $11 \beta$-Hydroxysteroid dehydrogenase 1 in adipocytes: expression is differentiation-dependent and hormonally regulated. Journal of Steroid Biochemistry and Molecular Biology 64 251-260. (doi:10.1016/ S0960-0760(97)00200-8)

Ossipow V, Descombes P \& Schibler U 1993 CCAAT/enhancer-binding protein mRNA is translated into multiple proteins with different transcription activation potentials. PNAS 90 8219-8223. (doi:10.1073/ pnas.90.17.8219)

Otto TC \& Lane MD 2005 Adipose development: from stem cell to adipocyte. Critical Reviews in Biochemistry and Molecular Biology 40 229-242. (doi:10.1080/10409230591008189)
Park EA, Gurney AL, Nizielski SE, Hakimi P, Cao Z, Moorman A \& Hanson RW 1993 Relative roles of CCAAT/enhancer-binding protein $\beta$ and cAMP regulatory element-binding protein in controlling transcription of the gene for phosphoenolpyruvate carboxykinase (GTP). Journal of Biological Chemistry 268 613-619.

Payne VA, Au WS, Gray SL, Nora ED, Rahman SM, Sanders R, Hadaschik D, Friedman JE, O'Rahilly S \& Rochford JJ 2007 Sequential regulation of diacylglycerol acyltransferase 2 expression by CAAT/enhancer-binding protein $\beta(\mathrm{C} / \mathrm{EBP} \beta)$ and $\mathrm{C} / \mathrm{EBP} \alpha$ during adipogenesis. Journal of Biological Chemistry 282 21005-21014. (doi:10.1074/jbc.M702871200)

Ramji DP \& Foka P 2002 CCAAT/enhancer-binding proteins: structure, function and regulation. Biochemical Journal 365 561-575.

Rosen ED \& MacDougald OA 2006 Adipocyte differentiation from the inside out. Nature Reviews. Molecular Cell Biology 7 885-896. (doi:10.1038/nrm2066)

Sai S, Esteves CL, Kelly V, Michailidou Z, Anderson K, Coll AP, Nakagawa Y, Ohzeki T, Seckl JR \& Chapman KE 2008 Glucocorticoid regulation of the promoter of $11 \beta$-hydroxysteroid dehydrogenase type 1 is indirect and requires CCAAT/enhancer-binding protein- $\beta$. Molecular Endocrinology 22 2049-2060. (doi:10.1210/me.2007-0489)

Seckl JR, Morton NM, Chapman KE \& Walker BR 2004 Glucocorticoids and $11 \beta$-hydroxysteroid dehydrogenase in adipose tissue. Recent Progress in Hormone Research 59 359-393. (doi:10.1210/rp.59.1.359)

Shin KJ, Wall EA, Zavzavadjian JR, Santat LA, Liu J, Hwang JI, Rebres R, Roach T, Seaman W, Simon MI et al. 2006 A single lentiviral vector platform for microRNA-based conditional RNA interference and coordinated transgene expression. PNAS 103 13759-13764. (doi:10.1073/pnas.0606179103)

Shoelson SE, Lee J \& Goldfine AB 2006 Inflammation and insulin resistance. Journal of Clinical Investigation 116 1793-1801. (doi:10.1172/ JCI29069)

Siu F, Chen C, Zhong C \& Kilberg MS 2001 CCAAT/enhancer-binding protein- $\beta$ is a mediator of the nutrient-sensing response pathway that activates the human asparagine synthetase gene. Journal of Biological Chemistry 276 48100-48107. (doi:10.1074/jbc.M109533200)

Smink JJ, Begay V, Schoenmaker T, Sterneck E, de Vries TJ \& Leutz A 2009 Transcription factor $\mathrm{C} / \mathrm{EBP} \beta$ isoform ratio regulates osteoclastogenesis through MafB. EMBO Journal 28 1769-1781. (doi:10.1038/emboj. 2009.127)

Thurmond DC, Ceresa BP, Okada S, Elmendorf JS, Coker K \& Pessin JE 1998 Regulation of insulin-stimulated GLUT4 translocation by Munc18c in 3T3L1 adipocytes. Journal of Biological Chemistry 273 33876-33883. (doi:10.1074/jbc.273.50.33876)

Tilghman SM, Hanson RW, Reshef L, Hopgood MF \& Ballard FJ 1974 Rapid loss of translatable messenger RNA of phosphoenolpyruvate carboxykinase during glucose repression in liver. PNAS 71 1304-1308. (doi:10.1073/pnas.71.4.1304)

Welm AL, Timchenko NA \& Darlington GJ 1999 C/EBP $\alpha$ regulates generation of $\mathrm{C} / \mathrm{EBP} \beta$ isoforms through activation of specific proteolytic cleavage. Molecular and Cellular Biology 19 1695-1704.

Wethmar K, Begay V, Smink JJ, Zaragoza K, Wiesenthal V, Dorken B, Calkhoven CF \& Leutz A 2010 C/EBP $\beta$ DUORF mice - a genetic model for uORF-mediated translational control in mammals. Genes and Development 24 15-20. (doi:10.1101/gad.557910)

Yang Z, Zhu X, Guo C \& Sun K 2009 Stimulation of 11 $\beta$-HSD1 expression by IL-1 $\beta$ via a C/EBP binding site in human fetal lung fibroblasts. Endocrine 36 404-411. (doi:10.1007/s12020-009-9245-4)

Yeh WC, Cao Z, Classon M \& McKnight SL 1995 Cascade regulation of terminal adipocyte differentiation by three members of the C/EBP family of leucine zipper proteins. Genes and Development 9 168-181. (doi:10.1101/gad.9.2.168)

Received in final form 22 April 2013

Accepted 25 April 2013

Accepted Preprint published online 25 April 2013 http://jme.endocrinology-journals.org

DOI: 10.1530/JME-13-0029 (c) 2013 The authors Printed in Great Britain
Published by Bioscientifica Ltd 